\section{APPLICATION OF INTEGRATED MULTI TROPIC AQUACULTURE CONCEPT IN AN ABRADED BRACKISH WATER POND}

\author{
Sri Rejeki*,Restiana Wisnu Ariyati, Lestari Lakhsmi Widowati
}

Aquaculture Study Program, Fisheries Department Faculty of Fisheries and Marine Science, Diponegoro University Semarang, Indonesia
Article history

Received 4 November 2015

Received in revised form

22 January 2016.

Accepted

5 February 2016

*Corresponding author sri_rejeki7356@yahoo.co.uk

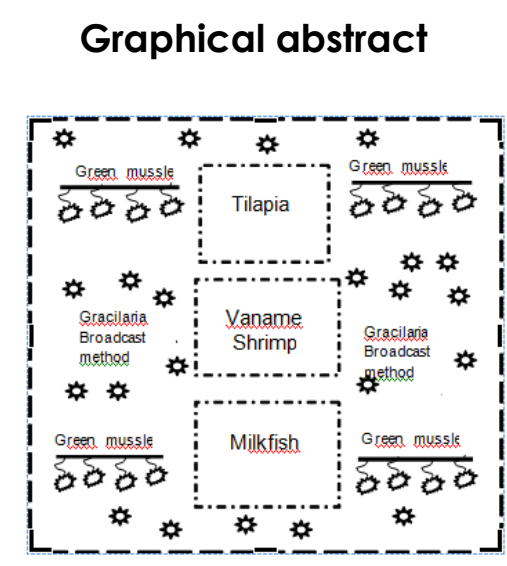

\begin{abstract}
Currently, abrasion at the northern coastline of Central Java, Indonesia, is severe. One of the biggest abrasion area is in Kaliwlingi village (Brebes District), where 800 ha of brackish water ponds were submerged. Abrasion could wipe away or damage dykes on brackish water pond and the pond can no longer be used for aquaculture production. A $5000 \mathrm{~m}^{2}$ of netting broken dyke of brackish water pond is used for semi-intensive cultivation of milkfish, tilapia, vanamae shrimp, green mussel and Gracilaria seaweed as an application of Integrated Multi Trophic Aquaculture (IMTA) concept. The aim of this study was to determine the aquaculture production in abraded dyke on brackish water pond by measuring the growth of milk fish, tilapia, vaname shrimp, green mussel and Gracilaria based on IMTA concept. The study was carried out from May to July 2015 at Kaliwlingi Village, Brebes district. The results showed Specific Growth Rate (SGR), i.e. milk fish $2.35 \%$ d1; tilapia $3.8 \% \cdot d^{-1}$ vanamae shrimp $3.75 \% \mathrm{~d}^{-1}$; green mussel $2.8 \% \mathrm{~d}^{-1}$ and Gracilaria $4.6 \% \mathrm{~d}^{-}$ 1 . Based on the result, the water quality is good and the availability of the natural food can support the growth of milkfish, tilapia, vanamae shrimp, green muscle and seaweed at broken dyke ponds with IMTA concept.
\end{abstract}

Keywords: Brackish water pond, coastal abration, IMTA, SGR

(C) 2016 Penerbit UTM Press. All rights reserved

\subsection{INTRODUCTION}

Coast is an important area which is very vurnarable to problems such as abrasion. Currently, abrasion at northern coastline of Central Java, Indonesia. is severe. Data from the Central Java Environmental Impact Management Agency showed that total abraded area at northern part of Central Java coastline was more than 5500 ha, spread across 10 districts. One of the biggest abrasion phenomenon is in Brebes district, especially at Kaliwlingi village. Coastal erosion at Kaliwingi village has submerged 800 ha brackish water ponds [1]. Abrasion could wipe away or damage dyke of brackish water ponds destroy the pond construction, thus, the pond can no longer be used for aquaculture production. As a result, the ponds become unproductive for aquaculture activities.

Abraded area has evoked problems for fish farmers, therefore, there is a need to consider ways to regain its productivity. The question is how the area can be reutilized for aquaculture production in order to help fish farmers generate income. Although it is physically damage, ecologically the water is still suitable for coastal aquaculture [2]. Therefore, setting a fixed net cage in the broken dykes' pond, netting the broken dykes and applying Integrated Multi Trophic Aquaculture (IMTA) concept could be the answer. 
Integrated Multi Tropic Aquaculture (IMTA) is an aquaculture concept which can improve efficiency and productivity of an aquaculture area. IMTA is a recycling concept where waste from higher tropic level will become an input energy for lower tropic organism such as bivalves [3]. This concept is employing many species based on their biologically characteristics. Waste from aquaculture species (e.g. finfish, shrimp) are assimilated by organic extractive species (e.g. mussel, sea cucumbers and sea urchins) and inorganic extractive species (e.g. seaweed) that are cultivated alongside the fish or shrimp. The characteristics of shrimp, milkfish and seaweed have made the IMTA concept possible to be implemented since these species supports each other's needs. Seaweeds provide oxygen through photosynthesis and they also have capability to absorb excess nutrients and toxic pollution in waters, while milkfish acts as plankton controller. Seaweeds also increase the quality of pond environment and become good ecology for milkfish. Shrimp and fish feces and other organic compounds can be used by seaweeds and phytoplanktons for their growth. Therefore, besides seaweed, milkfish, green mussel and vanamae shrimps are economically important species, and they can also be cultivated with this IMTA concept. The excretion of fish or shrimp from an intensive or semi-intensive culture provide $70 \%$ to $80 \%$ of ingested protein $\mathrm{N}$ that could reduce the water quality. IMTA made the development of nonpolluting cultivation more practical, both for mariculture and coastal environment [4].

The objective of this research is to determine an aquaculture production in abraded broken dyke on brackish water pond by measuring the growth of milk fish, tilapia, vaname shrimp, green mussel and Gracilaria based on IMTA concept.

\subsection{MATERIAL AND METHOD}

Materials used in this research were milk fish [Channos channos (Forsskål, 1775)], Tilapia [Oreochromis niloticus (Linnaeus, 1758)], shrimp [Pennaeus vanamae (Boone, 1931)], sea weed [Gracillaria verucosa (Hudson) Papenfuss, 1950] and green mussel [Verna viridis (Linnaeus, 1758)]. They were cultivated in cages that were set in netting brackish water ponds at Kaliwlingi Village, Brebes District, Central Java, Indonesia.

The integrated system consisted of three semi-intensive fixed net cages of $3 \mathrm{~m} \times 5 \mathrm{~m} \times 1 \mathrm{~m}$ located in a netting broken dykes brackish water pond, the water height in the cage was $50 \mathrm{~cm}$ to 70 $\mathrm{cm}$ approximatelly. The cage was stocked with fingerling of milkfish (1.71 \pm 0.09$) \mathrm{g}$ individual body weight); tilapia (1.20 \pm 0.18$) \mathrm{g}$ individual body weight), vanamae shrimp post larvae (0.43 \pm 0.02$) \mathrm{g}$ individual body weight), green mussel spat (3.22 \pm $0.08) \mathrm{g}$ individual body weight; shell length of $2.30 \pm$ $0.45) \mathrm{cm}$, and Gracilaria seed $100 \mathrm{~g}$ per knot. Fish and shrimp Ade cultivated semi-intensively in the individual fixed net cage of $3 \mathrm{~m} \times 5 \mathrm{~m} \times 1 \mathrm{~m}$. The stocking density of milkfish and tilapia were 750 fingerling per $15 \mathrm{~m}^{3}$. The vaname shrimp was 300 post larve per $15 \mathrm{~m}^{3}$ and was fed with pelleted feed $(2 \%$ per total body weigt per day). The green mussle was cultivated using long line method with stocking density of 40 spats per line. There were 50 lines of green mussle. While gracilaria was cultivated using broadcast method. To make easier during the study, $100 \mathrm{~g}$ of Gracilaria was tied in a knot prior to spreading at the bottom of the pond. There were 50 knots of Gracilaria cultivated in this research. The fish and shrimp cages, the green mussle long lines and the broadcast knots of Gracilaria were located in the netting of abraded dykes on brackish water pond. Lay out design of IMTA concept is shown in Figure 1.

The growth data of cultivated organisms were collected at the beginning and at the end of the research because it was too risky to collect their growth data more often, i.e. either weekly or monthly. Furthermore, the growth data collection in this research were more complicated compared to growth data collection in the laboratory.

The growth and water quality data were collected weekly. The Specific Growth Rate (SGR) of the milkfish, tilapia, vanamae shrimp, green mussle and Gracilaria were calculated with Eg. (1) as reference [5]

$S G R=\frac{\operatorname{Ln} W t-\operatorname{Ln} W o}{t} \times 100 \%$

\footnotetext{
SGR = Specific Growth Rate $\left(\% \cdot d^{-1}\right)$

Wo = initial weight $(g)$

Wt $=$ weight at the end of the cultivation

$\dagger \quad=$ duration of cultivation (d)
} 


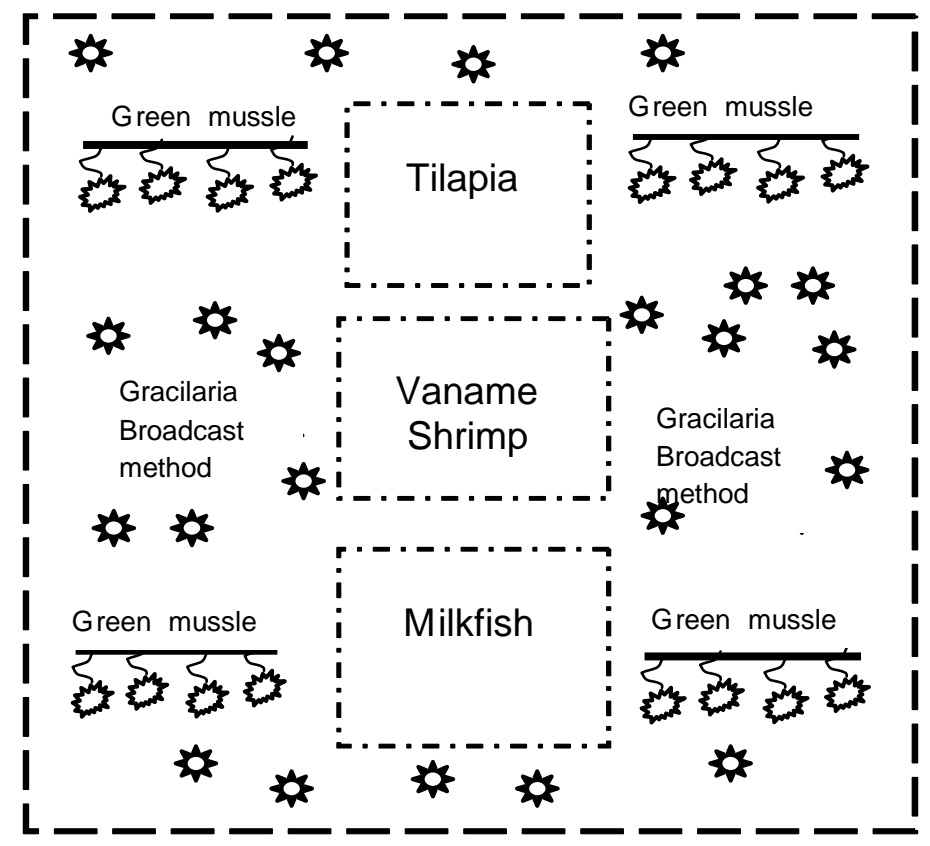

Figure 1 Lay out design of IMTA concept in the netting broken dyke brackish

Plankton community stucture was observed to find out the quality of water by filtering $100 \mathrm{~L}$ of water from $1 \mathrm{~m}$ below water surface using plankton net. The filtered water was then kept in the $100 \mathrm{~mL}$ bottle and preserved using $4 \%$ formalin. The plankton identification is based on [6]. The identified plankton was then analysed with Eg. 2 and Eq. 3.

1) Abundancy:

$$
N=\frac{n \times \text { sample volume }}{\text { identified volume } \times \text { filt ered volume }} \times 1000
$$

2) Diversity index of Shannon Weaver

$$
H=-\sum_{i=1}^{n} \frac{n i}{N} \ln \frac{n i}{N}
$$

$N=$ abundancy $\left(\right.$ cel $\left.\cdot L^{-1}\right)$

$\mathrm{n}=$ total number of planon

$\mathrm{H}^{\prime}=$ diversity index

$\mathrm{Ni}=$ individual number of each type

Criteria:

$\mathrm{H}^{\prime}<1=\quad$ Unstable community, heavily polluted

$1<\mathrm{H}^{\prime}<3=$ Moderately stable community; moderately polluted

$H^{\prime}>3=\quad$ Stable community; slightely to unpolluted.

The study was done from May to July 2015 at Kaliwlingi Village, Brebes District.

\subsection{RESULTS AND DISCUSSION}

The results shows that all cultivated organisms, i.e. milk fish, tilapia, vanamae shrimp, green mussel and Gracilaria could grow well as shown by the SGR value in Table 1.

Table 1 Growth, survival rate, and production of IMTA's organism in $60 \mathrm{~d}$ cultivation

\begin{tabular}{lc}
\hline Organisms & SGR $\left(\% \cdot \mathbf{d}^{-1}\right) \pm$ SD \\
\hline Milkfish & $2.34 \pm 0.19$ \\
Tilapia & $3.07 \pm 0.31$ \\
Vaname Shrimp & $3.83 \pm 0.20$ \\
Green Mussle & $2.82 \pm 0.09$ \\
Gracilaria & $4.60 \pm 0.16$ \\
\hline SD = Standard Deviation &
\end{tabular}

Based on field survey and measurement, the results of water quality parameters biologically, chemically and physically during the research are presented in Table 2 and 3.

Table 2 Diversity index of plankton

\begin{tabular}{lrrr}
\hline Diversity Index & May & June & July \\
\hline N (abundances) & 130.92 & 179.32 & 255.22 \\
H' (diversity) & 2.93 & 2.62 & 2.51 \\
e (evenness) & 0.95 & 0.88 & 0.83 \\
SI (Saprobhic Index) & 1.1 & 1.11 & 0.9 \\
TSI (Tropic Saprobic Index) & 1.53 & 1.38 & 1.47 \\
\hline
\end{tabular}

Table 3 Water quality

\begin{tabular}{lll}
\hline Parameters & Value & Reference \\
\hline Temperature $\left({ }^{\circ} \mathrm{C}\right)$ & $29-32$ & $18-33[7]$ \\
$\mathrm{pH}$ & $7.9-8.4$ & $6.5-8.5[8]$ \\
Salinity $(\% \circ)$ & $27-31$ & $15-38[7]$ \\
Dissolved oxygen $\left(\mathrm{mg} \cdot \mathrm{L}^{-1}\right)$ & $4.9-6.4$ & $4.1-6.6[9]$ \\
Depth $(\mathrm{cm})$ & $40-60$ & $50-150[8]$ \\
Current $\left(\mathrm{cm} \cdot \mathrm{sed}^{-1}\right)$ & $14-44$ & $10-30[10]$ \\
Nitrate $\left(\mathrm{mg} \cdot \mathrm{L}^{-1}\right)$ & $0.01-1.45$ & $0.9-3.5[7]$ \\
Phosphate $\left(\mathrm{mg}^{\left.-\mathrm{L}^{-1}\right)}\right.$ & $0.24-5.97$ & $0.1-0.2[11]$ \\
\hline
\end{tabular}

High value of SGR (Table 1) does not indicate better growth. The SGR of Gracilaria $4.60 \% \pm 0.16 \%$ $\mathrm{d}^{-1}$ was the highest among other cultivated organisms. This may be due to its capability to absorb excess nutrients [11]. SGR value of tilapia $(3.07 \% \pm$ $0.31 \% \mathrm{~d}^{-1}$ ) is considered good value as mentioned by other experiment for genetic assessment of Nila Pandu [12] that in the three months on the nursery phase of tilapia the SGR value was $3.02 \% \mathrm{~d}^{-1}$. On the other hand, the SGR value of milk fish is $2.34 \% \pm 0.19$ 
$\% \mathrm{~d}^{-1}$ is consistent with SNI (Indonesian National Standard) No. 01- 6149-1999 [13]. While the SGR of vaname shrimp $3.83 \% \pm 0.20 \% \mathrm{~d}^{-1}$ was considered as optimal growth as stated [14] in which SGR of vaname shrimp at the age of $40 \mathrm{~d}$ to $70 \mathrm{~d}$ was between the ranges of (3.53 to 4.46$) \% d^{-1}$. Other organisms is green muscle as a filter feeder organisms which showed SGR of $(2.82 \pm 0.09) \% d^{-1}$. This result was higher comparing with other experience that cultivated green mussels in abraded ponds in Morosari, Demak District. Their result shown, the growth rate of green mussels was considered good, approximately $2.55 \% \mathrm{~d}^{-1}$ [2]. From May to July 2015 green muscle increased their length on average (4.1 $\pm 0.11) \mathrm{mm} \mathrm{d}^{-1}$ during $60 \mathrm{~d}$ of cultivation. Same phenomenon occured in the other research result that cultivate abalone in IMTA System [15], the growth rate of the abalone in juvenile stage has 5.9 $\mathrm{mm} \mathrm{d}^{-1}$.

Based on the IMTA concept, the role and growth of each organism in the whole system start from algae (seaweed) in which photosynthesis introduces new Energy from organic carbon that comes from nutrient in the water. Amination of the newly fixed carbon by algae assimilates inorganic nitrogen back are useful algal protein. This is a modification of controlled eutrophication concept. This concept makes eutrophication beneficial by applying it within cultivation system and using it to desirable organism [15].

IMTA is a concept of practical farming, in which organic and inorganic waste derived from feed for finfish and crustacean (tilapia, milkfish and vanamae shrimp) are assimilated by extractive organic species (green mussel) and inorganic extractive species, i.e. seaweed, Gracillaria [16]. Seaweed can remove 35 $\%$ to $100 \%$ dissolved nitrogen produced by decomposition of waste foof and excretion of fish or shrimp [17]. In seaweed cultivation in open water, nutrients released from fish feed waste could be used as a nutrient for the seaweed growth [18].

seaweeds are able to grow due to photosynthesis. Photosynthesis uses inorganic in which $\mathrm{CO}_{2}$ combines with sunlight and chlorophyll and to produce carbohydrate for seaweed's growth and oxygen for the environment. Ammonia as organic materials which is derived from feed and faeces decomposition was used by seaweed as a nutrient source and may provide oxygen for water and reduce the level of $\mathrm{CO}_{2}$ [19].

Some factors have to be considered in the application of IMTA concept, such as selection of farmed fish, farm design and fish feed and cultivation environment. The growth of each organism is affected by the amount of feed and water quality as growth media The SGR value of milk fish and tilapia as well as the vanamae shrimp are considered good, since in the semi-intensive cultivation system the cultivated organisms are fed using pelleted feed approximately $2 \%$ of biomass weight, and also from availability of natural food in the system (Table 1). Research has been carried out by in South Sumatera with tiger shrimp aquaculture organisms, milk fish and seaweed (Euchema cottonii and Gracillaria sp) [20]. The result showed that the cultivated organisms could grow well. It was shown by the value of SGR of $7.963 \%$ for shrimp, and $6.86 \%$ for milk fish after $80 \mathrm{~d}$ cultivation. This suggests that the growth of shrimp and milk fish can be carried out simultaneously on IMTA farming system. That finding is similar to other research that cultivate three organisms (tiger prawn, milk fish and seaweed) in polyculture system which showed a mutual synergy [11]. Environment is a factor that has indirect effect on the growth. Good or favorable environmental condition promotes the growth of cultivated organisms optimally. The aquaculture concept always tries to make a good quality of environment to the growth. In this research, water quality parameters physically, chemically and biologically were in good range for organisms' growth (Table 2).

Vanamae shrimp is more sensitive than other organisms. This shrimp needs stable condition for their life and growth. Fluctuate condition in salinity and/or $\mathrm{pH}$ can cause stress and thus, it can be easily infected by bacteria or viruses. This is because the stress on shrimp was responded by moulting, and during the moulting, the shrimp is in a weak condition. The SGR of the shrimp was $3.83 \% \mathrm{~d}^{-1}$, it meaning that the metabolism of the vanamae shrimp was not disturbed, thus, the shrimp could grow well in such environment. Metabolism is a mechanism for organisms to grow by increasing the body weight. In this process, organisms make a complex mechanism which is a combination factor of feeding, environment, and genetic. Optimum growth occurs when all those factor are in the right combination and become good mechanism, thus lead to a good result such as increased body weight. Feeding frequency for vanamae is twice a day with dose was $2 \%$ of body weight.

Tilapia and milk fish growth from feed showed SGR of $2.34 \% \mathrm{~d}^{-1}$ and $3.07 \% \mathrm{~d}^{-1}$, respectively. It means that the milkfish and tilapia could growth well in IMTA cultivation system in this area. The same result was found in West Sumatera [21] dan South Sumatera [22] that milk fish growth in polyculture system with Gracillaria seaweed has SGR of $1.84 \% \mathrm{~d}^{-1}$, and SR of $80.74 \%$. In this research the SGR of milkfish was higher (3.07\%) compared to their finding. Therefore, IMTA cultivation concept for semi-intensive cultured system of milkfish and tilapia can be applied for coastal aquaculture development. In semi-intensive culture system, feed was given twice per day as much as $2 \%$ of biomass body weight of cultured organisms. From the SGR point of view, it can be considered that the dose and frequency of feed for milk fish and tilapia was desirable. The Researcher of Maros Research Institute for Brackish Water Aquaculture found that growth mechanism happened when the feed was kept by the cultivated organisms for their life and growth [4]. The other researcher also mentioned that the cultivated organisms grew by increasing volume, length and biomass on a specific time [22]. 
Considering the environmental condition of the location, where temperature was $25^{\circ} \mathrm{C}$ to $32{ }^{\circ} \mathrm{C}$, $\mathrm{pH}$ was 6.5 to 8.5 , more than $3 \mathrm{mg} \mathrm{L}^{-1}$ of dissolved oxygen and $0.02 \mathrm{mg} \mathrm{L}^{-1}$ of ammonia, those parameters were suitable for milkfish and tilapia as standardized by BSN 2009 [13]. Tilapia is known as fresh water fish, however, this fish is a euryhaline organism and can be cultivated in the salinity range between $25 \mu \mathrm{g} \mathrm{L}^{-1}$ to $32 \mu \mathrm{g} \mathrm{L}^{-1}$. Milkfish is herbivore which is fed with filamentous alga and lablab, thus becomes a natural bio security for unwanted weeds that disturb seaweed growth. Research finding in south Sumatera mentioned that good density for milk fish was $1500 \mathrm{ha}^{-1}$, and that milk fish stocking density would not disturb the seaweed growth [21].

Gracilaria seaweed as a macro alga needs solar energy for photosynthesis and nutrient ( $\mathrm{N}$ and $\mathrm{P}$ ) to be able to grow. The value of $N$ in this area is 0 to $1.45 \mathrm{mg} \mathrm{L}^{-1}$ which is in the range for good growth for Gracillaria. The minimum concentration of nitrate for Gracilaria is $0.21 \mathrm{mg} \mathrm{L}^{-1}$ and not more than $4.5 \mathrm{mg} \mathrm{L}^{-1}$ [4]. Phosphate range in the cultivation location was between 0.31 to $0.56 \mathrm{mg} \mathrm{L} \mathrm{L}^{-1}$. This phosphate concentration was in optimum range for good growth of Gracilaria [3]. Gracilaria needs nitrate and phosphate for the growth, and fewer amount of those nutrients leads to slow growth. Nitrate and phosphate come from the decomposition of feed waste and faeces of milkfish, tilapia and vanamae shrimp. Light can penetrate until the bottom of cultivation pond and based on field analysis, light can penetrate $1.5 \mathrm{~m}$. Gracilaria seaweed provides dissolved oxygen (DO) supply at daylight because of photosynthesis activity. The increase of DO in the water can be used by bacteria to decompose the organic material. Furthermore, the increase of DO content in the system can promote the reduction of ammonia content which is harmful to the cultured organisms. The reduction of ammonia due to chemical processes leads to the increase of ammonium and nitrate that can be used for seaweed growth. Other advantage of Gracilaria seaweed cultivation using IMTA concept is that the blooming of harmful plankton like dinoflagellata can be avoided.

Green mussel is as a filter feeder organism that has a high tolerance to the environmental conditions. However, the availability of plankton as its natural feed should be considered. Mussels are filter feeder, in which they consume plankton by filtering the water. The abundance of phytoplankton and other sources such as macrophyte or resuspended detritus (Table 1) is the main source of feed for the green mussels [22]. Other research was done in Polyculture System of Salmon [23], concluded that M. edulis as a filter feeder was able to capture and absorb fish feed waste from commercial salmon farms and use it as a potential feed source. It can be seen by its assimilation efficiency (40 \%) when the green mussel was fed with fish feed waste and algae. The study about Pacific Oyster implies that fish faeces could be captured and absorbed by bivalve, although bivalve absorbed diatom species more effective $56 \%$ absorption efficiency was found in Casostrea gigas which was fed with faeces from farm waste, and increased by $66 \%$ when it was fed with diatom S.costatum. Furthermore, it was mentioned that the growth rate of green mussels depend on the abundance of feed and physical and chemical factors of the cultivation environment [23]. Based on previous research [7], there were 23 species and 114 ind $\mathrm{L}^{-1}$ plankton found in Kaliwlingi, which was dominated by diatom. Other research were observed in Coastal Georgia United State found that diatom was the primary food for green mussel. Other variable that is important to make decision for mussels' selection is heavy metals content. Based on the feeding behaviour of green mussels as filter feeder, they can easily absorb heavy metals form substrate and sediment. Saprobic index can be used as pollution indicator. High concentration of heavy metals is normally found in polluted water. Table 1 provides information that saprobic index in the research site is 0.9 to 1.53 , which can be categorized as alpha mesosaprobic to beta mesosaprobic condition, meaning that the location is low to moderately polluted. Other research where observed in Demak District reported that in mesosaprobic level, the heavy metal content (Pb) in organism cultivated in brackish water pond of Semarang district was 10.27 to 0.39$) \mathrm{mg} \mathrm{L}^{-1}$ [30]. Which is still in tolerable acceptance for food consumption base on SNI 7378:2009

The temperature range between $28^{\circ} \mathrm{C}$ to $32^{\circ} \mathrm{C}$ is in tolerable range for all cultivated organisms. The optimum temperature for shrimp cultivated in the brackish water pond is between $28^{\circ} \mathrm{C}$ to $32{ }^{\circ} \mathrm{C}$. Temperature is one of important variable for organism because it could affect the metabolism activity [21]. Dissolved oxygen is important factor for respiration. The DO content in the water for aquaculture activity should be more than $3 \mathrm{mg} \mathrm{L}^{-1}$. In the IMTA concept, availability of DO in the water is supported by seaweed as the result of photosynthesis during the day. However, at night the DO content decreases because it is used by seaweed for respiration. The $\mathrm{pH}$ range during this research was 7.9 to 8.4 which was considered good for aquatic organisms to live and grow. Other water quality variable which has an important effect is salinity. The salinity during the research in the cultivation site was (27 to 31 ) $\mathrm{Mg} \mathrm{L}^{-1}$ approximately. This salinity range is in the tolerable range for cultivated organism. Osmoregulation affected by salinity which used to keep the bodily fluid from being too diluted or too concentrated.

\subsection{CONCLUSION}

Based on this research can be concluded that abraded brackish water pond at Kaliwlingi village Brebes district can be used for applying Integrated 
Multi Tropic Aquaculture (IMTA) concept since the water quality is good and the availability of the natural food can support the growth of cultivated organisms: milkfish, tilapia, vanamae shrimp, green mussel and Gracilaria seaweed

\section{Acknowledgement}

Great appreciation is adressed to Depatment of Fiisheries and Marine affair Brebes district for funding this research

\section{References}

[1] Dinas Perikanan dan Kelautan Kabupaten Brebes. 1999. Potensi Budidaya Pesisir Kabupaten Brebes, Brebes dalam Angka [Potential Coastal Aquaculture of Brebes District, Brebes in Number). Institution of Marine and Fisheries Brebes District. Brebes. [Bahasa Indonesia].

[2] Rejeki, S., R. W. Ariyati, and L. L. Widowati. 2014. Evaluasi Kelayakan Ekologi Tambak Terabrasi untuk Pengelolaan Budidaya Laut berdasar Analisis Tropic Saprobik Index di Desa Kaliwlingi Kabupaten Brebes [Evaluation of Ecological Suitability of Abraded Brackish Water Pond Waters for Maricalture Based on the Trophic Saprobic Index Analyses at Kaliwlingi Village Brebes District]. In Anggo, A. D., S. Hastuti, and Suryanti (eds.). Proceeding of National Seminar Year IV of Research results on Fisheries and Marine Sciences. 2014 November 1-2. Semarang, Indonesia. 48-53. [Bahasa Indonesia).

[3] Irisarri J, M. J. F Reiriz, U. Labarta, and P. J. Cranford 2015. Availability and Utilization of Waste Fish Feed by Mussels Mytilus edulis in a Commercial Integrated Multi-trophic Aquaculture (IMTA) System: A Multi-Indicator Assessment Approach. Ecological Indicators. 48: 673-686.

[4] Neori, A., M. Shipigel, and D. Ben-Ezra. 2000. A Sustainable Integrated System of Culture of Fish, Seaweed and Abalone. Aquaculture Elsevier. 186: 279-291.

[5] Guo, H., J. Yau, Z. Sun, and D. Duan 2015. Effect of Salinity and Nutrient on the Growth and Chlorophyl Fluoresence of Caulerpha lentifera. Chinese Journal of Oceanology and Limnology. 33(2): 410-418.

[6] Sachlan, M. 1982. Planktonologi. Semarang: Diponegoro University. [Bahasa Indonesia].

[7] Akmal, Ilham, M. Suaib, Irwan and M. Arifin, 2008. Produksi Spora Dalam Upaya Penyediaan Bibit Rumput Laut Gracilaria verrucosa [Spora Production to Provide the Gracilaria verucosa Seaweed Seed]. Paper presented at: Indonesian Aquaculture Seminar; 17-20 November 2008; Yogyakarta. [Bahasa Indonesia].

[8] Ahda, A., A. Surono, and B. Imam. 2005. Profil Rumput Laut Indonesia [Indonesia Seaweed Profile]. Jakarta: Marine Affairs and Fisheries of Indonesia. [Bahasa Indonesia].

[9] Putra W. S. 2006. Laju Filtrasi Kerang Hijau (Perna viridis) dalam Mereduksi Material Terlarut [Filtration Rate of Green Mussle (Perna viridis) in Reducing the Suspended Material]. Bogor: Bogor Agricultural Institute. [Bahasa Indonesia].

[10] Porsepwandi. 1998. Reduksi Kandungan Hg dan Kualitas Kerang Hijau (Mytilus viridis) [The Reduction of Hg Content and Green Mussle (Mytilusviridis) Quality]. Thesis. Bogor: Bogor Agricultural Institute. [Bahasa Indonesia].
[11] Mangampa, M. and Burhanuddin. 2014. Uji Lapang Polikultur Udang Windu, Bandeng, dan Rumput Laut Gracilaria di Tambak Desa Borimasunggu Kabupaten Maros [Field Experiment on Polyculture of Tiger Shrimp, Milk Fish and Gracilaria Seaweed in the Brackish Water Pond at Borimasunggu Village Maros District]. Saintek Perikanan, Indonesian Journal of Fisheries and Technology. 10(1): 3036. [Bahasa Indonesia].

[12] Setiyono, E., F. Basuki, and S. Hastuti, 2014. Analysis of Genetic Gain Tilapia Pandu F-5 at Nursery I - III. Journal of Aquaculture Management and Technology. 1 (1): 77-86.

[13] Badan Standarisasi Nasional. 1999. Standar Nasional Indonesia (SNI). SNI 01-6149-1999. Benih Ikan Bandeng (Chanos chanos Forskal) Kelas Benih Sebar [Milk Fish (Chanos chanos Forskal) Rearing Stage Larve]. Dewan Standarisasi Indonesia. Jakarta. [Bahasa Indonesia].

[14] Siboro, G. F., Melki and Isnaini. 2014. Pengaruh Padat Tebar Berbeda terhadap Laju Pertumbuhan Udang Windu (Penaeus monodon), Bandeng (Chanos chanos) and Rumput Laut (Eucheuma cottonii, Gracilaria sp.) secara Polikultur di Desa Sungai Lumpur OKI Kabupaten Sumatera Selatan [The Effect of Different Stocking Densities on the Growth Rate of Tiger Shrimp (Penaeus monodon), Milk Fish (Chanos chanos) and Seaweed (Eucheuma cottonii, Gracilaria sp.) on Polyculture Method at Sungai Lumpur Village OKI South Sumatera District. Maspari Journal. 6(1): 46-55. [Bahasa Indonesia].

[15] Shigel, M. and A. Neori. 1995. The Integrated Culture of Seaweed, Abalone, Fish and Clams in Modular Intensive Land-based Systems: I. Proportions of Size and Projected Revenues. Aquaculture Engineering Elsevier. 15(5): 313326.

[16] Erfan, A. H., P. Brata, and M. Markus. 2010. Polikultur Udang Vaname dan Rumput Laut [Polyculture of Vaname Shrimp (Litopenaus vannamei) and Seaweed (Gracilaria verrucosa)]. South Sulawesi: Maros Research Institute for Brackish Water Aquaculture. [Bahasa Indonesia].

[17] Troell, M., C. Halling, A. Neori, A. H. Buschmann, T. Chopin, C. Yarish, et al. 2003. Integrated Mariculture: Asking the Right Questions. Aquaculture. 226: 69-90.

[18] Troell, M., A. Joyce, T. Chopin, A. Neori, A. H. Bushmann. 2009. Ecological Engineering in Aquaculture - Potential for Integrated Multi-Tropic Aquaculture in Marine Offshore System. Aquaculture. 297: 1-9.

[19] Schuenhoff, A., M. Shpigel, I. Lupatsch, A. Askenazi, F. E, Msuya, and A.Neori, 2003. A Semi-recirculating, Integrated System for the Culture of Fish and Seaweed. Aquaculture. 221: 167-181.

[20] Nurdin, J., N. Marusin, A. Izmiati, A. Asmara, R. Deswandi, and J. Marzuki, 2006. Kepadatan Populasi Kerang Darah Anadara antiquata di Teluk Sungai Pisang Sumatera Barat [Population Density of Blood Cockle Anadara antiquata in Sungai Pisang Bay West Sumatera]. Makara Sains. 10(2): 96-101. [Bahasa Indonesia].

[21] Efendi. 2003. Analisis Kualitas Air untuk Lingkungan dan Sumberdaya Perairan [The Water Quality Analysis for Environment and Aquatic Resources Management]. Yogyakarta: Kanisius. [Bahasa Indonesia].

[22] Sallih. 2005. Mussel Farming in the State of Sarawak Malaysia: A Feasibility Study. Final Project. Iceland: The United Nations University.

[23] MacDonald B. A., S. M. C. Robinson, and K. A. Barrington. 2011. Feeding Activity of Mussles (Mytilus edulis) Held in the Field at an Integrated Multi Trophic Aquaculture (IMTA) Site (Salmosalar) and Exposes to Fish Food in the Laboratory. Aquaculture Elsevier. (314): 244-251.

[24] Lefebvre, S., L. Barille, and M. Clerc. 2000. Pacific Oyster (Crassostrea gigas) Feeding Responses to a Fish Farm Effluent. Aquaculture Elsevier. 187(1-2): 185-198. 